\title{
NF-KB in Male Reproduction: A Boon or a Bane?
}

\author{
Premendu P. Mathur ${ }^{2}$, Mary Francispillai ${ }^{1}$, Selvaraju Vaithinathan ${ }^{2}$ and Ashok Agarwal ${ }^{*}, 1$ \\ ${ }^{I}$ Center for Reproductive Medicine, Cleveland Clinic, 9500 Euclid Avenue, Cleveland, OH 44195, USA \\ ${ }^{2}$ Department of Biochemistry and Molecular Biology, School of Life Sciences, Pondicherry University, Pondicherry, \\ 605 014, India
}

\begin{abstract}
The apoptotic process involved in the male reproductive system regulates the ability of the male to fertilize and pass on his genes through the process of spermatogenesis. Numerous factors are involved in mediating this essential and intricate process. It is known that without programmed cell death there would be an overwhelming amount of chaos within the seminiferous tubules of the testis, which would lead to dysfunctional spermatogenesis, and problems within the male reproductive system. Of the factors effecting testicular apoptosis, we are interested in studying the effects of Nuclear Factor kappa B (NF- $\mathrm{KB})$ as well as select cytokines as they appear to have a significant role in germ cell death. Other mediators will also be briefly discussed in this paper.
\end{abstract}

Keywords: Apoptosis, spermatogenesis, nuclear factor-kappa B.

\section{INTRODUCTION}

\subsection{Spermatogenesis/ Steroidogenesis-Overview}

A quick overview of spermatogenesis permits us to see that it is a complex process allowing for the maturation and proliferation of male germ cells [1-3]. The onset of puberty allows diploid spermatogonia to turn into mature spermatozoa within the seminiferous tubules of the testes $[4,5]$. Spermatogenesis takes places specifically within the seminiferous epithelium of the seminiferous tubules and is divided into four separate phases; namely mitosis, meiosis, spermiogenesis and spermiation [6]. Throughout this process the cells are slowly moving from the basement membrane towards the lumen where the mature spermatozoa will be released, and through contractile movements will migrate to the epididymis where they are stored for a brief period until they reach full maturity and motility [5]. This entire process is termed the seminiferous epithelial cycle of spermatogenesis. It can be broken into six small stages in men, twelve in mice and fourteen in rats based on differing morphological criteria [7-10].

Spermatogenesis cannot properly proceed without hormonal support from the hypothalamic-pituitary-gonadal axis [11]. Gonadotropin releasing hormone $(\mathrm{GnRH})$ release from the hypothalamus stimulates the secretion of Luteinizing hormone (LH) and Follicle stimulating hormone (FSH) from the anterior pituitary. LH binds to receptors on the Leydig cells thereby promoting production of testosterone, a crucial hormone involved in spermatogenesis and male sexual characteristics. FSH, also produced by the anterior pituitary, works on the Sertoli cells to produce androgen binding protein which is required for concentrating amounts of

*Address correspondence to this author at the Center for Reproductive Medicine, Cleveland Clinic, 9500 Euclid Avenue, Cleveland, Ohio 44195, USA; Tel: 216-444-9485/ 216-444-4402; Fax: 216-636-3118/ 216-4456049; E-mail: agarwaa@ccf.org testosterone within the testes mediating proper progression of spermatogenesis.

\section{MECHANISM OF ACTION OF APOPTOSIS}

\subsection{Physiological Role of Apoptosis in Maintaining Spermatogenesis}

In order for the complex phenomenon of diploid spermatogonia converting into mature haploid spermatozoa there needs to be a proper environment surrounding the cells. This is provided by the Sertoli cells. They provide nutrients and support to allow for the growth and development of the germ cells. To attain optimal sperm output the number of germ cells needs to be within the nurturing capacity of the Sertoli cells [12], therefore to ensure that these sustentacular cells do not get overwhelmed and that spermatogenesis can correctly take place, programmed germ cell death must occur. Up to $75 \%$ of the possible number of mature sperm cells get deleted via this mechanism [13]. This form of controlled apoptosis is mediated by many factors, among which nuclear factor kappa B is included [14]. It is important to note that not all cells undergoing spermatogenesis are apoptotic. It was found that the main NF- $\mathrm{KB}$ complex was constitutively expressed within Sertoli cells but immunostaining of rat seminiferous tubules showed that Nuclear Factor kappa B (NF-kB) was present in a stage-specific manner in spermatocytes and spermatids alone and that these were the cells undergoing programmed cell death [4]. Research thus far has not conclusively determined whether or not the same applies for human testes.

\subsection{General Mechanism of Action Apoptosis-ROS as Mediator}

As mentioned apoptosis plays a critical role within the male reproductive system. It allows for elimination of unwanted, harmful cells [15], promotes complete differentiation and maintains homeostasis within the organism. 
Inhibition of cell death increases the likelihood of developing malignancies and over-activating apoptosis can lead to massive destruction of cellular systems. With regards to the male system apoptosis is essential during spermatogenesis to allow for proper germ cell development and maturation [14].

There are different apoptotic stimuli that can initiate programmed cell death. The type of apoptosis that occurs depends greatly upon the type of stimuli present [16]. An elevated level of reactive oxygen species (ROS) induces damage to cellular structures, because their unpaired valence electrons makes them highly reactive and creates an environment conducive to cell damage and death. Due to the fact that Sertoli cells can create an environment abundant in free radicals testicular germ cells are particularly susceptible to ROS and oxidative stress [17]. A study conducted by Ikeda et al. determined that the formation of free radical species within the testis or within the spermatozoa would increase as the temperature increased, meaning cell death is a temperature-dependent process. Ikeda et al. used varying concentrations of xanthine and xanthine oxidase, which produce reactive oxygen species, to deduce whether or not ROS would indeed lead to testicular apoptosis, as hypothesized. Upon exposure, DNA gel electrophoresis showed DNA fragmentation patterns characteristic of apoptosis. Also, this study demonstrated that apoptosis was dose-dependent, so that increasing concentrations of xanthine lead to a similar increase in dead/dying cells [18]. Oxidative stress markers within testicular cells were elevated upon exposure to tertiary-butyl hydroperoxide (TBHP) coincidentally with an increase in nuclear factor kappa B expression. It is thought that this transcription factor is implicated in ROS-induced apoptosis where it leads to regulation of the germ cells present within the testis [19].

\section{NUCLEAR FACTOR-אB}

Nuclear factor-kappa B is a family of transcription factors implicated in numerous stress responses including apoptosis within male testicular cells $[20,21]$. NF- $\kappa \mathrm{B}$ exists as a homo- or heterodimer and is found within the cytoplasm of most mammalian cells. To date there have been 5 mammalian NF family members identified [20, 22, 23]; the most common being the NF- $\mathrm{BB} 1$ (p50) and RelA (p65) subunits [14]. The N-terminus, also called the Rel homology domain, is the mediator of NF- $\kappa \mathrm{B}$ 's interaction with I kappa $\mathrm{B}$ (an inhibitory factor), its dimerization, DNA binding and translocation into the nucleus [24]. The term "Rel" stems from the fact that these subunits share homology with the products of the c-rel oncogene, hence forming the Rel/NF$\mathrm{\kappa B}$ family of transcription factors [20, 25]. The classic proteins bind to specific DNA sequences termed $\kappa \mathrm{B}$ sites or $\kappa \mathrm{B}$ elements [22] with the consensus sequence 5'GGGRNNYYCC-3' [20]. The C-termini of the NF- $\kappa B$ proteins contain many copies of the ankyrin repeat which keep these proteins in an inactive, immature state [20, 22]. Processing entails degradation of these repeats to allow for mature, active proteins. In addition to these repeats the inactive NF- $\kappa B$ proteins are maintained as such through their interaction with the I $\kappa \mathrm{B}$ family. I $\kappa \mathrm{B}$ proteins are inhibitory factors located in the cytoplasm of most animal cells and similar to the NF proteins, there exists many different types of $I \kappa B$ proteins that interact with $N F-\kappa B$ based on individual affinities [26]. I $\mathrm{B}$ associates itself with the nuclear localization signal (NLS) of NF- $\kappa B$, which prevents the entry of NF- $\kappa B$ into the nucleus, therefore it remains in an inactive state. Stimulation via various extracellular stimuli activates the so-called I kappa B kinase (IאK) complex, which allows for the degradation of the inhibitory proteins.

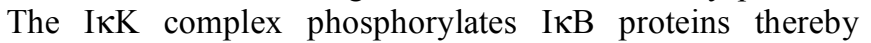
targeting them for ubiquitination and degradation by the $\mathrm{Ub} /$ proteosome complex $[27,28]$. Now the NLS of NF- $\kappa \mathrm{B}$ is exposed, allowing entry of NF- $\mathrm{KB}$ into the nucleus where it will allow transcription of different genes. An important role allocated to NF- $\kappa \mathrm{B}$ is the part it plays in allowing transcription of genes involved in germ cell apoptosis in male reproduction.

\subsection{Pro- and Anti-Apoptotic Role of NF- $\kappa$ B}

Pentikäinen et al. demonstrated that under serum free conditions, an excessive amount of apoptotic activity was seen in human seminiferous tubules, concomitant with increased amounts of NF- $\kappa B$ activity [14]. Yet to say that $\mathrm{NF}-\kappa \mathrm{B}$ promotes solely pro-apoptotic functions would be an inaccurate assumption. There are many proteins and factors associated with NF- $\mathrm{KB}$ that allow it to carry out its functions in regards to apoptosis of germ cells in different ways. Various studies have shown that NF- $\mathrm{BB}$ has both anti- and pro-apoptotic effects within cells yet how it's able to work as a double-edged sword is still unclear [29]. Based on recent evidence, the function of $\mathrm{NF}-\kappa \mathrm{B}$, whether or not it demonstrates pro- or anti-apoptotic activity, may be based largely on the environment and stimuli present [14]. Fas ligand (FasL), also known as the death promoting ligand [30], is a protein expressed by the Sertoli cells that belongs to the family of the tumor necrosis factor proteins [31-33]. It associates with the Fas receptor, which is a type I transmembrane receptor, located on the testicular germ cells and is involved in an apoptosis signal transduction pathway mediated by NF- $\mathrm{KB}[34,35]$. Through immunohistochemical experiments, Fas was localized to the same cells that were identified as apoptotic based on the presence of $N F-\kappa B$, namely the spermatocytes and spermatids [36]. Activation of $\mathrm{NF}-\kappa \mathrm{B}$ leads to the upregulation of gene expression of FasL and thereby promotes apoptosis of the germ cells [27, 37]. This pathway also involves numerous caspases. These proteins, belonging to the family of cysteine proteases, are what mediate cell death via proteolytic cleavage [38, 39]. They are synthesized as proenzymes and are activated upon cleavage by other proteases. The active form of this enzyme has proven to be a marker for cell apoptosis. Through the activation of adaptor proteins via the interaction between the FasL and the Fas receptor, caspase 8 is recruited, and starts a chain reaction where caspase 3 , and other effector caspases become triggered and eventually leads to germ cell death [22].

Sulfasalazine (SS), an anti-inflammatory agent, was used to determine what effects it may have on NF- $\kappa B$ and testicular germ cell apoptosis. In the presence of sulfasalazine both NF- $\kappa \mathrm{B}$ activation and germ cell apoptosis were inhibited. Experiments were conducted to determine if the 
effect of SS was through the inhibition of IкB degradation. Based on Western blot analysis of I $\kappa$ B-alpha exposed to SS it was seen that degradation of I $\kappa B$ still occurred as per usual even though levels of NF- $\kappa B$ were low. This suggests that sulfasalazine works on NF- $\kappa B$ through a mechanism unrelated to $\mathrm{I} \kappa \mathrm{B}$. The same study tested the effects of acetylsalicylic acid and $\mathrm{N}$-acetylcysteine on germ cell apoptosis, based on information gathered from previous research. Inhibition of germ cell apoptosis was observed, independent of $\mathrm{NF}-\kappa \mathrm{B}$ activity, implying that NF- $\kappa \mathrm{B}$ and its DNA binding activity remained intact. This finding may lead one to think that nuclear factor kappa B may not play as distinct a role as originally thought in regards to apoptosis but it's more likely that other parallel apoptotic pathways exist within the human testes that produce the different results seen, along with the

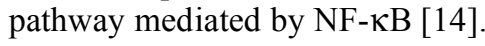

Another factor that affects $N F-\kappa B$ and its function is sphingosine-1-phosphate (S1P). S1P is a phospholipid that can be found distributed widely within mammalian cells and plays a key role in differentiation and apoptosis [40, 41]. This sphingolipid can inhibit apoptosis within human male germ cells and it does so independently of its own receptors. It is believed that S1P works as an intracellular second messenger and inhibits NF- $\mathrm{KB}$ [42] promoting anti-apoptotic effects. Seminiferous tubules cultured in serum-free conditions showed an increase in NF- $\kappa \mathrm{B}$ expression, but when treated with S1P NF- $\kappa \mathrm{B}$ activity was inhibited. It does so by suppressing the degradation of IKB alpha [43]. The Akt protein family, when phosphorylated and active, is responsible for controlling the IKK complex which in turn regulates I $\mathrm{KB}$ [44]. It was shown that S1P prevents phosphorylation of Akt therefore hindering the activation of $\mathrm{I} \kappa \mathrm{K}$, leading to inhibition of NF- $\mathrm{KB}$ and cell apoptosis [43].

As we know, FSH plays an important role in the process of spermatogenesis $[9,45]$. Binding of $\mathrm{FSH}$ to its receptors on Sertoli cells leads to activation of adenylyl cyclase and subsequently the production of cAMP. Through this pathway FSH indirectly leads to the activation of protein kinase A (PKA), which turns out to be a regulator of NF-KB [46]. An increase in levels of PKA causes an increase in NF- $\kappa B$ binding activity [4]. The way in which PKA controls NF- $\kappa B$ is through phosphorylation of $\mathrm{I} \kappa \mathrm{B}$, which leads to its degradation [47, 48]. A study conducted by Delfino et al. involved use of a molecule known as forskolin to study the effects of cAMP on NF- $\kappa B$. Forskolin is used to increase intracellular levels of cAMP and led to increases in NF- $\mathrm{B}$ binding activity. Comparing exposure of germ cells to FSH $v s$. forskolin shows that NF- $\kappa \mathrm{B}$ binding increased 4.5 fold with forskolin compared to 2.5 fold with FSH alone [4], showing the importance of the downstream effects of FSH, namely cAMP production

\subsection{Role of Cytokines in Apoptosis}

Many of the immune-related functions of the body are mediated by immunoregulatory proteins known as cytokines. They also have essential functions outside of the immune system, including autocrine, paracrine and endocrine functions that have an effect on proliferation, differentiation and more importantly, apoptosis of cells [49].
Tumor necrosis factor-alpha (TNF-alpha) is a cytokine produced mainly, but not solely, by macrophages. It has proinflammatory effects and is key in the maintenance of a hospitable environment within the testes [50]. Similar to Fas, TNF-alpha belongs to a superfamily of death ligands, which is currently made up of 19 members $[51,52]$. It mediates its effects through two receptors; TNFR1 (55 kDa) and TNFR2 $(75 \mathrm{kDa})$. Depending on the environment and the cell type TNF-alpha can either induce apoptosis or prevent it [53]. In the human testes it turns out to play an anti-apoptotic role via the activation of NF- $\mathrm{B}$ [50]. Upon binding of TNF-alpha to TNFR1, TNFR1 can recruit the adaptor molecule TRADD which binds to the cytoplasmic death domain of TNFR1. This then leads to the recruitment of another protein, TRAF2 and RIP, which culminates in the degradation of I $\mathrm{KB}$ through

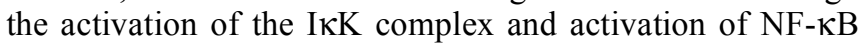
[54]. This then allows nuclear factor kappa B to upregulate the transcription of anti-apoptotic genes; namely cIAP1,2 and XIAP, to name a few [55-57]. An in vitro experiment conducted with a TNF inhibitor (infliximab) resulted in germ cell destruction within rat seminiferous tubules [53]. It has also been shown that TNF-alpha downregulates the Fas ligand within the human testes [30], thereby providing another pathway to inhibit germ cell apoptosis. This is proof of the multi-faceted role of NF- $\kappa \mathrm{B}$.

Interleukin 1 (IL-1) is one among a family of three 17 $\mathrm{kDa}$ proteins: IL-1 alpha, beta and IL-1 Ra (receptor antagonist) [58]. They are produced by testicular Sertoli cells [59-65] and through their activation they inhibit the production of testosterone that is stimulated by LH, human chorionic gonadotropin and cAMP [66-73]. Without the support from testosterone, cell apoptosis is greatly increased. This is mediated by both alpha and beta interleukin 1 . Though they only share $22 \%$ homology they bind the same receptor and carry out similar functions [49]. Based on experiments conducted in mice a decrease in testosterone can be seen when inhibition of cAMP leads to the decrease in the gene expression of P450c17 within Leydig cells, which normally allows for the conversion of cholesterol to androstenedione [69]. IL-2 also leads to an upregulation in apoptotic activity within testicular cells by affecting the expression of the $\mathrm{P} 450 \mathrm{c} 17$ gene. In this case there is an inhibition of GnRH-stimulated testosterone, instead of being mediated through levels of cAMP [74]. IL-2 also stimulates the secretion of other cytokines such as interferon gamma and IL-1 $[75,76]$. As is seen with many other cytokines interleukin 2 leads to elevated levels of glucocorticoids within the system, via interaction with the HypothalamicPitutary-Gonada (HPG) axis. This leads to suppressive effects on Leydig cell steroidogenesis and thus provides another means to promote apoptotic activity within the testes [77]. Interestingly IL-1 also promotes activation of NF- $\kappa \mathrm{B}$ through IкB phosphorylation [78].

The interferon family includes IFN-alpha, beta and gamma [49]. IFN-alpha and gamma predominate within the testis and are produced by macrophages, as well as Sertoli and Leydig cells [79, 80]. Again, there is a decrease in testosterone production associated with the interferon family, as seen within porcine Leydig cells $[81,82]$. IFN-gamma mediates this through down regulation of the $\mathrm{P} 450 \mathrm{c} 17$ gene, 
as well as inhibiting the transport of cholesterol into mitochondria [83].

Three of the five forms of Transforming Growth Factorbeta (TGF-beta) are found within mammals; TGF-beta 1, 2 and 3 [84]. As with the other cytokines described thus far it works by inhibiting steroidogenesis within Leydig cells by reducing the number of $\mathrm{LH}$ receptors as well as the signaling that accompanies it [85]. Direct germ cell apoptosis has also been demonstrated in the presence of TGF-beta 1 and 2 during early stages of spermatogenesis [86]. Levels of TGFbeta are tightly regulated within the testes through communication between the Leydig and Sertoli cells [86, 87].

Another cytokine includes epidermal growth factor which has been implicated in spermatogenesis and is known to be produced by Leydig cells, Sertoli cells, and other cell populations within the testes related to the functions of spermatogenesis $[88,89]$. Its exact role remains unclear, as does any connection to $\mathrm{NF}-\kappa \mathrm{B}$, but a correlation has been made between spermatogenic dysfunction and the expression of EGF in Sertoli cells [90].

Based on the available literature, there is some controversy in terms of the role cytokines play in testicular cell death, but the majority of the studies point to cytokines having pro-apoptotic effects, mediated largely via inhibition of steroidogenesis [91].

\section{OTHER FACTORS INFLUENCING APOPTOSIS IN TESTIS}

Other mediators apart from NF- $\mathrm{KB}$ and cytokines exist in promoting or inhibiting testicular apoptosis. The most studied is the B-cell lymphoma 2 family of genes. The bcl-2 gene family consists of both anti- and pro- apoptotic proteins. Bcl-2 and bcl-xl are among those involved in mediating cell survival, with Bcl-2 demonstrating antioxidant-like qualities [18], whereas bax and bcl-xS favor cell death [92]. An appropriate ratio of death promoting and death inhibiting bcl proteins are required to maintain optimal conditions within the testes.

There are also a wide variety of situations where the apoptosis involved in the physiological state of the testes can turn into one of pathological significance.

\subsection{Heat Stress}

Heat stress is a factor involved in germ cell apoptosis within the testes and can lead to a decrease in the fertilizing capability of a male [18]. Based on histochemical staining of adult rat testes it was seen that the main cells where an increase in apoptosis was observed due to high temperatures to the abdomen were the primary spermatocytes and the spermatids [93]. Another study conducted by Ikeda et al. showed distinct, prominent bands of fragmented DNA under heat stressed conditions compared to testicular cells cultured at $32.5^{\circ} \mathrm{C}$, which only showed minimal fragmentation [18]. Recent study demonstrated that pachytene spermatocytes in early and late stages as well as round spermatids of mice show morphological changes as seen with cells undergoing apoptosis after being submerged in hot water at $43^{\circ} \mathrm{C}$ for 15 $\min [94]$.

\subsection{Alcohol}

Copious amounts of alcohol has been shown to negatively impact the testes of male rats. The breakdown of ethanol leads to the production of reactive oxygen species via an increase in lipid peroxidation, resulting in apoptosis within the testes. Since alcohol possesses the ability to cross the blood-testis-barrier (BTB) it renders the testes increasingly susceptible to damage [95]. Levels of glutathione, a potent antioxidant, were also decreased in response to alcohol administration [96]. Again, apoptosis was seen primarily within spermatocytes and spermatogonia [97].

\subsection{Radiation}

Rasoulpour et al. demonstrated that exposure to radiation, specifically gamma-radiation, led to an upregulation of $\mathrm{NF}-\kappa \mathrm{B}$ activity. This in turn lead to pro-apoptotic effects in the cells involved [98]. Studies have shown that even low doses of radiation can have detrimental effects on spermatogonia $[99,100]$. Further research is required to determine the exact mechanism of action of radiation in accordance with $\mathrm{NF}-\kappa \mathrm{B}$ and cell death.

\subsection{Restraint Stress}

Immobilization stress (restraint stress) induces suppression of spermatogenesis and upregulation of apoptosis within the testicular cells of rats. The reasoning behind this is that there is a decrease in the function of the HPG axis which is an important regulator of testicular function. Stress brings about an increase in production of corticosterone which has a negative effect on the HPG axis. This leads to a decrease in $\mathrm{GnRH}$ release which ends in the inhibition of testosterone [101]. The testes no longer have the ability to support themselves and therefore die through programmed cell death.

\subsection{Smoking}

Studies have shown that smoking reduces the number of germ cells present, increases apoptosis in genital cells and induces major changes in the morphology of the testicular tissue. Using testes of human fetuses, Coutts et al. demonsrated the effect environmental toxicants, such as those found in cigarette smoke, have on the male reproductive system. In the presence of DMBA-DHD, the active metabolite of polycyclic aromatic hydrocarbons (PAH), there was upregulation of factors involved in apoptosis; namely bax. There was also upregulation of aryl hydrocarbon receptors (ARH), through which PAH mediate their apoptotic effects [102], proving the detrimental effects that smoking can have on the male reproductive system

\subsection{Drugs}

There exists a multitude of drugs that have negative outcomes on the structural and functional properties of sperm and the testes. One example would be hydroxyurea (HU), an antineoplastic drug used commonly in myoproliferative disorders. Shin et al. showed that dose-dependent administration of HU leads to programmed cell death of the mouse germ cells. The mechanism is thought to involve the ability of HU to inhibit ribonucleotide reductase, causing a 
decrease in the amount of DNA precursors required for DNA synthesis. Its effects were restricted to germ cells of already damaged tubules [103].

\section{EXPERT COMMENTARY}

Various studies have shown that the role of apoptotic cell death within the male testes corresponds to a vital facet of survival and propagation of healthy, viable sperm. NF- $\mathrm{KB}$ has proven to be of great importance when it comes to programmed cell death because of it's ability to act as a double-edged sword, being pro-apoptotic in one instance and anti-apoptotic in another. The effect of cytokines also plays a huge role in this process and a sizable body of literature has demonstrated that the outcome within the testes is based largely on the surrounding stimuli and the different effects they have on these modulators.

\section{FIVE-YEAR REVIEW}

In the past few years, apoptosis has attained much attention. NF- $\kappa B$ has been reported to act as stress sensor. Activation of NF- $\mathrm{KB}$ results in upregulation of various genes related to apoptosis of germ cells. A few studies have reported the involved of $\mathrm{NF}-\mathrm{\kappa B}$ in toxicant-induced testicular injury. Further studies are warranted to understand the role of cytokines and NF- $\mathrm{KB}$ in testis during pathological conditions.

\section{KEY POINTS}

- Observations provoke us to hypothesis that NF- $\mathrm{kB}$ could be a key determinant in executing ROS-mediated apoptosis in spermatogenic cells of testis following exposure to environmental toxicants.

- During severe stress NF- $\kappa B$ activation protects the Sertoli cells themselves and simultaneously induces the activation of Sertoli cell gene(s) that exerts proapoptotic effects on germ cells.

- Dysregulation in the expression of NF- $\mathrm{KB}$ in testis following toxicant exposure could also have impact on other factors involved in the regulation of testicular functions.

\section{ACKNOWLEDGEMENT}

P. P. Mathur acknowledges the receipt of financial support from the Department of Science and Technology, Government of India under the projects, 1) SP/SO/B-65/99. 2) DST-FIST 2009. 3) Indian Council of Medical Research, New Delhi. 4) Department of Biotechnology, New Delhi. 5) Department of Information Technology, New Delhi for Centre of Excellence in Bioinformatics. The authors also thank the staff of Bioinformatics Center, Pondicherry University, Pondicherry for providing various facilities.

\section{CONFLICT OF INTEREST}

None Declared.

\section{REFERENCES}

[1] de Kretser DM, Loveland KL, Meinhardt A, Simorangkir D, Wreford N. Spermatogenesis. Hum Reprod 1998; 13 (Suppl 1): 18.

[2] de Rooij DG. Proliferation and differentiation of spermatogonial stem cells. Reproduction 2001; 121: 347-54.

[3] Print CG, Loveland KL. Germ cell suicide: new insights into apoptosis during spermatogenesis. Bioessays 2000; 22: 423-30.

[4] Delfino F, Walker WH. Stage-specific nuclear expression of NFkappaB in mammalian testis. Mol Endocrinol 1998; 12: 1696-707.

[5] Sadler TW. Langman's Medical Embryology. Lippincott Williams \& Wilkins, 2006.

[6] Cheng CY, Wong EW, Yan HH, Mruk DD. Regulation of spermatogenesis in the microenvironment of the seminiferous epithelium: new insights and advances. Mol Cell Endocrinol 2010; 315: 49-56.

[7] de Kretser D, Kerr J. The cytology of the testis. Raven Press: New York 1988.

[8] Mruk DD, Cheng CY. Sertoli-Sertoli and Sertoli-germ cell interactions and their significance in germ cell movement in the seminiferous epithelium during spermatogenesis. Endocr Rev 2004; 25 : 747-806.

[9] Sharpe RM. Regulation of spermatogenesis. Raven Press: New York 1994.

[10] Walker WH. Molecular mechanisms of testosterone action in spermatogenesis. Steroids 2009; 74: 602-7.

[11] Meng J, Holdcraft RW, Shima JE, Griswold MD, Braun RE. Androgens regulate the permeability of the blood-testis barrier. Proc Natl Acad Sci U S A 2005; 102: 16696-700.

[12] Griswold MD. The central role of Sertoli cells in spermatogenesis. Semin Cell Dev Biol 1998; 9: 411-6.

[13] Dunkel L, Hirvonen V, Erkkila K. Clinical aspects of male germ cell apoptosis during testis development and spermatogenesis. Cell Death Differ 1997; 4: 171-9.

[14] Pentikainen V, Suomalainen L, Erkkila K, et al. Nuclear factorkappa B activation in human testicular apoptosis. Am J Pathol 2002; 160: 205-18.

[15] Strasser A, O'Connor L, Dixit VM. Apoptosis signaling. Annu Rev Biochem 2000; 69: 217-45.

[16] Wolbers F, Buijtenhuijs P, Haanen C, Vermes I. Apoptotic cell death kinetics in vitro depend on the cell types and the inducers used. Apoptosis 2004; 9: 385-92.

[17] Bauche F, Fouchard MH, Jegou B. Antioxidant system in rat testicular cells. FEBS Lett 1994; 349: 392-6.

[18] Ikeda M, Kodama H, Fukuda J, et al. Role of radical oxygen species in rat testicular germ cell apoptosis induced by heat stress. Biol Reprod 1999; 61: 393-9.

[19] Kaur P, Kaur G, Bansal MP. Tertiary-butyl hydroperoxide induced oxidative stress and male reproductive activity in mice: role of transcription factor NF-kappaB and testicular antioxidant enzymes. Reprod Toxicol 2006; 22: 479-84.

[20] Baldwin AS Jr. The NF-kappa B and I kappa B proteins: new discoveries and insights. Annu Rev Immunol 1996; 14: 649-83.

[21] Pahl HL. Activators and target genes of Rel/NF-kappaB transcription factors. Oncogene 1999; 18: 6853-66.

[22] Chen F, Castranova V, Shi X , Demers LM. New insights into the role of nuclear factor-kappaB, a ubiquitous transcription factor in the initiation of diseases. Clin Chem 1999; 45: 7-17.

[23] Ghosh S, May MJ, Kopp EB. NF-kappa B and Rel proteins: evolutionarily conserved mediators of immune responses. Annu Rev Immunol 1998; 16: 225-60.

[24] Siebenlist U, Franzoso G, Brown K. Structure, regulation and function of NF-kappa B. Annu Rev Cell Biol 1994; 10: 405-55.

[25] Baeuerle PA, Henkel T. Function and activation of NF-kappa B in the immune system. Annu Rev Immunol 1994; 12: 141-79.

[26] Karin M. How NF-kappaB is activated: the role of the IkappaB kinase (IKK) complex. Oncogene 1999; 18: 6867-74.

[27] Israel A. The IKK complex: an integrator of all signals that activate NF-kappaB? Trends Cell Biol 2000; 10: 129-33.

[28] Palombella VJ, Rando OJ, Goldberg AL, Maniatis T. The ubiquitin-proteasome pathway is required for processing the NFkappa B1 precursor protein and the activation of NF-kappa B. Cell 1994; 78: 773-85.

[29] Kaltschmidt B, Kaltschmidt C, Hofmann TG, Hehner SP, Droge $\mathrm{W}$, Schmitz ML. The pro- or anti-apoptotic function of NF-kappaB 
is determined by the nature of the apoptotic stimulus. Eur $\mathrm{J}$ Biochem 2000; 267: 3828-35.

[30] Pentikainen V, Erkkila K, Suomalainen L, et al. TNFalpha downregulates the Fas ligand and inhibits germ cell apoptosis in the human testis. J Clin Endocrinol Metab 2001; 86: 4480-8.

[31] Nagata S, Golstein P. The Fas death factor. Science 1995; 267 : 1449-56.

[32] Richburg JH, Nanez A, Williams LR, Embree ME, Boekelheide K. Sensitivity of testicular germ cells to toxicant-induced apoptosis in gld mice that express a nonfunctional form of Fas ligand. Endocrinology 2000; 141: 787-93.

[33] Suda T, Takahashi T, Golstein P, Nagata S. Molecular cloning and expression of the Fas ligand, a novel member of the tumor necrosis factor family. Cell 1993; 75: 1169-78.

[34] Itoh N, Yonehara S, Ishii A, et al. The polypeptide encoded by the cDNA for human cell surface antigen Fas can mediate apoptosis. Cell 1991; 66: 233-43.

[35] Oehm A, Behrmann I, Falk W, et al. Purification and molecular cloning of the APO-1 cell surface antigen, a member of the tumor necrosis factor/nerve growth factor receptor superfamily. Sequence identity with the Fas antigen. J Biol Chem 1992; 267: 10709-15.

[36] Pentikainen V, Erkkila K, Dunkel L. Fas regulates germ cell apoptosis in the human testis in vitro. Am J Physiol 1999; 276: E310-6.

[37] Ashkenazi A, Dixit VM. Death receptors: signaling and modulation. Science 1998; 281: 1305-8.

[38] Cohen GM. Caspases: the executioners of apoptosis. Biochem J 1997; 326 ( Pt 1): 1-16.

[39] Nicholson DW , Thornberry NA. Caspases: killer proteases. Trends Biochem Sci 1997; 22: 299-306.

[40] Pyne S, Tolan DG, Conway AM, Pyne N. Sphingolipids as differential regulators of cellular signalling processes. Biochem Soc Trans 1997; 25: 549-56.

[41] Spiegel S, Milstien S. Sphingosine-1-phosphate: an enigmatic signalling lipid. Nat Rev Mol Cell Biol 2003; 4: 397-407.

[42] Hla T. Signaling and biological actions of sphingosine 1-phosphate. Pharmacol Res 2003; 47: 401-7.

[43] Suomalainen L, Pentikainen V, Dunkel L. Sphingosine-1phosphate inhibits nuclear factor kappaB activation and germ cell apoptosis in the human testis independently of its receptors. Am J Pathol 2005; 166: 773-81.

[44] Datta SR, Brunet A, Greenberg ME. Cellular survival: a play in three Akts. Genes Dev 1999; 13: 2905-27.

[45] Plant TM, Marshall GR. The functional significance of FSH in spermatogenesis and the control of its secretion in male primates. Endocr Rev 2001; 22: 764-86.

[46] Kangasniemi M, Kaipia A, Mali P, Toppari J, Huhtaniemi I , Parvinen M. Modulation of basal and FSH-dependent cyclic AMP production in rat seminiferous tubules staged by an improved transillumination technique. Anat Rec 1990; 227: 62-76.

[47] Ghosh S , Baltimore D. Activation in vitro of NF-kappa B by phosphorylation of its inhibitor I kappa B. Nature 1990; 344: 67882.

[48] Shirakawa F, Mizel SB. In vitro activation and nuclear translocation of NF-kappa B catalyzed by cyclic AMP-dependent protein kinase and protein kinase C. Mol Cell Biol 1989; 9: 242430 .

[49] Hales DB, Diemer T, Hales KH. Role of cytokines in testicular function. Endocrine 1999; 10: 201-17.

[50] Barkett M, Gilmore TD. Control of apoptosis by Rel/NF-kappaB transcription factors. Oncogene 1999; 18: 6910-24.

[51] Aggarwal BB, Kohr WJ, Hass PE, et al. Human tumor necrosis factor. Production, purification, and characterization. J Biol Chem 1985; 260: 2345-54.

[52] Pennica D, Nedwin GE, Hayflick JS, et al. Human tumour necrosis factor: precursor structure, expression and homology to lymphotoxin. Nature 1984; 312: 724-9.

[53] Suominen JS, Wang Y, Kaipia A, Toppari J. Tumor necrosis factor-alpha (TNF-alpha) promotes cell survival during spermatogenesis, and this effect can be blocked by infliximab, a TNF-alpha antagonist. Eur J Endocrinol 2004; 151: 629-40.

[54] Hsu H, Shu HB, Pan MG, Goeddel, DV. TRADD-TRAF2 and TRADD-FADD interactions define two distinct TNF receptor 1 signal transduction pathways. Cell 1996; 84: 299-308.

[55] Dahl AM, Klein C, Andres PG, et al. Expression of bcl-X(L) restores cell survival, but not proliferation off effector differentiation, in CD28-deficient T lymphocytes. J Exp Med 2000; 191: 2031-8

[56] LaCasse EC, Baird S, Korneluk RG, MacKenzie AE. The inhibitors of apoptosis (IAPs) and their emerging role in cancer. Oncogene 1998; 17: 3247-59.

[57] Reed JC. Bcl-2 family proteins. Oncogene 1998; 17: 3225-36.

[58] Dinarello CA. The interleukin-1 family: 10 years of discovery. FASEB J 1994; 8: 1314-25.

[59] Cudicini C, Kercret H, Touzalin AM, Ballet F, Jegou B. Vectorial production of interleukin 1 and interleukin 6 by rat Sertoli cells cultured in a dual culture compartment system. Endocrinology 1997; 138: 2863-70.

[60] Gerard N, Syed V, Bardin W, Genetet N, Jegou B. Sertoli cells are the site of interleukin-1 alpha synthesis in rat testis. Mol Cell Endocrinol 1991; 82: R13-6.

[61] Gerard N, Syed V, Jegou B. Lipopolysaccharide, latex beads and residual bodies are potent activators of Sertoli cell interleukin-1 alpha production. Biochem Biophys Res Commun 1992; 185: 15461 .

[62] Hoeben E, Wuyts A, Proost P, Van Damme J, Verhoeven G. Identification of IL- 6 as one of the important cytokines responsible for the ability of mononuclear cells to stimulate Sertoli cell functions. Mol Cell Endocrinol 1997; 132: 149-60.

[63] Okuda Y, Sun XR, Morris PL. Interleukin 6 (IL-6) mRNAs expressed in Leydig and Sertoli cells are regulated by cytokines, gonadotropins and neuropeptides. Endocrine 1994; 2: 617- 24.

[64] Syed V, Gerard N, Kaipia A, Bardin CW, Parvinen M, Jegou B. Identification, ontogeny, and regulation of an interleukin-6-like factor in the rat seminiferous tubule. Endocrinology 1993; 132: 293-9.

[65] Syed V, Stephan JP, Gerard N, et al. Residual bodies activate Sertoli cell interleukin-1 alpha (IL-1 alpha) release, which triggers IL-6 production by an autocrine mechanism, through the lipoxygenase pathway. Endocrinology 1995; 136: 3070-8.

[66] Calkins JH, Guo H, Sigel MM, Lin T. Differential effects of recombinant interleukin-1 alpha and beta on Leydig cell function. Biochem Biophys Res Commun 1990; 167: 548-53.

[67] Calkins JH, Sigel MM, Nankin HR, Lin T. Interleukin-1 inhibits Leydig cell steroidogenesis in primary culture. Endocrinology 1988; 123: 1605-10.

[68] Fauser BC, Galway AB, Hsueh AJ. Inhibitory actions of interleukin-1 beta on steroidogenesis in primary cultures of neonatal rat testicular cells. Acta Endocrinol (Copenh) 1989; 120: 401-8.

[69] Hales DB. Interleukin-1 inhibits Leydig cell steroidogenesis primarily by decreasing 17 alpha-hydroxylase/C17-20 lyase cytochrome P450 expression. Endocrinology 1992; 131: 2165-72.

[70] Mauduit C, Chauvin MA, Hartmann DJ, Revol A, Morera AM, Benahmed M. Interleukin-1 alpha as a potent inhibitor of gonadotropin action in porcine Leydig cells: site(s) of action. Biol Reprod 1992; 46: 1119-26.

[71] Moore C, Moger WH. Interleukin-1 alpha-induced changes in androgen and cyclic adenosine 3',5'-monophosphate release in adult rat Leydig cells in culture. J Endocrinol 1991; 129: 381-90.

[72] Verhoeven G, Cailleau J, Van Damme J, Billiau A. Interleukin-1 stimulates steroidogenesis in cultured rat Leydig cells. Mol Cell Endocrinol 1988; 57: 51-60.

[73] Xiong Y, Hales DB. Immune-endocrine interactions in the mouse testis: cytokine mediated inhibition of Leydig cell steroidogenesis. Endocr J 1994; 2: 223-28.

[74] Guo H, Calkins JH, Sigel MM, Lin T. Interleukin-2 is a potent inhibitor of Leydig cell steroidogenesis. Endocrinology 1990; 127: 1234-9.

[75] Kasahara T, Hooks JJ, Dougherty SF, Oppenheim JJ. Interleukin 2mediated immune interferon (IFN-gamma) production by human $\mathrm{T}$ cells and T cell subsets. J Immunol 1983; 130: 1784-9.

[76] Nedwin GE, Svedersky LP, Bringman TS, Palladino MA Jr., Goeddel DV. Effect of interleukin 2, interferon-gamma, and mitogens on the production of tumor necrosis factors alpha and beta. J Immunol 1985; 135: 2492-7.

[77] Hales DB, Payne AH. Glucocorticoid-mediated repression of P450scc mRNA and de novo synthesis in cultured Leydig cells. Endocrinology 1989; 124: 2099-104.

[78] Beg AA, Finco TS, Nantermet PV, Baldwin AS Jr. Tumor necrosis factor and interleukin-1 lead to phosphorylation and loss of I kappa 
B alpha: a mechanism for NF-kappa B activation. Mol Cell Biol 1993; 13: 3301-10.

[79] Dejucq N, Lienard MO, Guillaume E, Dorval I, Jegou B. Expression of interferons-alpha and -gamma in testicular interstitial tissue and spermatogonia of the rat. Endocrinology 1998; 139: 3081-7.

[80] Kanzaki M, Morris PL. Identification and regulation of testicular interferon-gamma (IFNgamma) receptor subunits: IFNgamma enhances interferon regulatory factor-1 and interleukin-1beta converting enzyme expression. Endocrinology 1998; 139: 2636-44.

[81] Orava M. Comparison of the inhibitory effects of interferons-alpha and -gamma on testosterone production in porcine Leydig cell culture. J Interferon Res 1989; 9: 135-41.

[82] Orava M, Cantell K, Vihko R. Human leukocyte interferon inhibits human chorionic gonadotropin stimulated testosterone production by porcine Leydig cells in culture. Biochem Biophys Res Commun 1985; 127: 809-15.

[83] Orava M, Voutilainen R, Vihko R. Interferon-gamma inhibits steroidogenesis and accumulation of mRNA of the steroidogenic enzymes P450scc and P450c17 in cultured porcine Leydig cells. Mol Endocrinol 1989; 3: 887-94.

[84] Meinhardt A, O'Bryan MK, McFarlane JR, et al. Localization of follistatin in the rat testis. J Reprod Fertil 1998; 112: 233-41.

[85] Saez JM, Lejeune H. Regulation of Leydig cell functions by hormones and growth factors other than LH and IGF-1. In: Payne AH, Hardy MP, Russell LD Eds. The Leydig Cell. Vienna, IL: Cache River Press 1996; pp. 383-406.

[86] Olaso R, Pairault C, Boulogne B, Durand P, Habert R. Transforming growth factor beta1 and beta2 reduce the number of gonocytes by increasing apoptosis. Endocrinology 1998; 139: 73340 .

[87] Gautier C, Levacher C, Saez JM, Habert R. Expression and regulation of transforming growth factor beta1 mRNA and protein in rat fetal testis in vitro. Biochem Biophys Res Commun 1997; 236: $135-9$.

[88] Niederberger CS, Shubhada S, Kim SJ, Lamb DJ. Paracrine factors and the regulation of spermatogenesis. World J Urol 1993; 11: 1208.

[89] Yan YC, Sun YP, Zhang ML. Testis epidermal growth factor and spermatogenesis. Arch Androl 1998; 40: 133-46.

[90] Nakazumi H, Sasano H, Maehara I, Orikasa S. Transforming growth factor-alpha, epidermal growth factor, and epidermal growth factor receptor in human testis obtained from biopsy and castration: immunohistochemical study. Tohoku J Exp Med 1996; 178: 381-8.

[91] Hales DB.Macrophage-Leydig Cell Interactions: An Overview. In: Payne AH, Hardy MP, Russell LD Eds. The Leydig Cell. Vienna, IL: Cache River Press 1996; pp. 451-66.

[92] Sinha AP, Swerdloff RS. Hormonal and genetic control of germ cell apoptosis in the testis. Rev Reprod 1999; 4: 38-47.

[93] Yin Y, Hawkins KL, DeWolf WC, Morgentaler A. Heat stress causes testicular germ cell apoptosis in adult mice. J Androl 1997; 18: 159-65.

[94] Nakai A, Suzuki M, Tanabe M. Arrest of spermatogenesis in mice expressing an active heat shock transcription factor 1. EMBO J 2000; 19: 1545-54.

[95] Maneesh M, Jayalekshmi H, Dutta S, Chakrabarti A, Vasudevan DM. Role of oxidative stress in ethanol induced germ cell apoptosis. An experimental study in rats. Indian J Clin Biochem 2005; 20: 62-67.

[96] Rosenblum ER, Gavaler JS, Van Thiel DH. Lipid peroxidation: a mechanism for alcohol-induced testicular injury. Free Radic Biol Med 1989; 7: 569-77.

[97] Zhu Q, Meisinger J, Emanuele NV, Emanuele MA, LaPaglia N, Van Thiel DH. Ethanol exposure enhances apoptosis within the testes. Alcohol Clin Exp Res 2000; 24: 1550-6.

[98] Rasoulpour RJ, Boekelheide K. NF-kappaB activation elicited by ionizing radiation is proapoptotic in testis. Biol Reprod 2007; 76: 279-85.

[99] Kovacs GT, Stern K. Reproductive aspects of cancer treatment: an update. Med J Aust 1999; 170: 495-7.

[100] Oakberg EF. Sensitivity and time of degeneration of spermatogenic cells irradiated in various stages of maturation in the mouse. Radiat Res 1955; 2: 369-91.

[101] Gindoff PR, Ferin M. Endogenous opioid peptides modulate the effect of corticotropin-releasing factor on gonadotropin release in the primate. Endocrinology 1987; 121: 837-42.

[102] Coutts SM, Fulton N, Anderson RA. Environmental toxicantinduced germ cell apoptosis in the human fetal testis. Hum Reprod 2007; 22: 2912-8.

[103] Shin JH, Mori C, Shiota K. Involvement of germ cell apoptosis in the induction of testicular toxicity following hydroxyurea treatment. Toxicol Appl Pharmacol 1999; 155: 139-49.

(C) Mathur et al.; Licensee Bentham Open.

This is an open access article licensed under the terms of the Creative Commons Attribution Non-Commercial License (http://creativecommons.org/licenses/by$\mathrm{nc} / 3.0 /$ ), which permits unrestricted, non-commercial use, distribution and reproduction in any medium, provided the work is properly cited. 